\title{
The Development of Descriptive Text Materials Oriented to High Order Thinking Abilities for Seven Graders of Secondary Schools
}

\author{
Rahmat Agung Mulyana*, Jaja, Yusida Gloriani \\ Department of Bahasa Indonesia Education, Postgraduate School, Universitas Swadaya Gunung Jati, Cirebon, Indonesia
}

Email address:

rahmatagungmulyana@gmail.com (R. A. Mulyana)

*Corresponding author

\section{To cite this article:}

Rahmat Agung Mulyana, Jaja, Yusida Gloriani. The Development of Descriptive Text Materials Oriented to High Order Thinking Abilities for Seven Graders of Secondary Schools. International Journal of Secondary Education. Vol. 9, No. 1, 2021, pp. 17-25.

doi: 10.11648/j.ijsedu.20210901.13

Received: January 25, 2021; Accepted: February 2, 2021; Published: February 26, 2021

\begin{abstract}
This research is a development research which aims to produce printed teaching materials in the form of descriptive textbooks oriented to higher order thinking skills (HOTS). This research is used as a student training material and a source of teacher teaching materials related to solving problems that require students to think critically and creatively. The product of this textbook development is divided into four parts, namely the book cover, which contains front and back covers, the first two parts of the book, namely, contain a copyright page, an introduction, a table of contents, general instructions, a columnhots, scientific columns, concept maps, and descriptive text learning objectives. Furthermore, the three content sections, which contain the contents of the book, are divided into four basic competencies of descriptive text for class VII SMP/MTs (seven graders of secondary schools), and the fourth is the final part of the book, which contains a bibliography, glossary, and author's curriculum vitae. This study uses the Research and Development method (R\&D with the ADDIE Model. Data were collected using interviews by five Indonesian language teacher practitioners, then documentary studies to obtain the structure of language rules, then filling out a questionnaire to obtain the results of validation of material and media experts by two respondents and an implementation questionnaire. by three Indonesian language teacher practitioners The results of the development of HOTS-oriented descriptive text books for grade VII which have been validated by material experts with a score of $84 \%$ (quite valid) and media experts with a score of $82 \%$ (quite valid). implemented to test its feasibility on three Indonesian teacher respondents with indicators including: 1) content, 2) language, 3) presentation of the material, 4) graphics, and 5) HOTS components got $89 \%$ gain. Thus the HOTS-oriented descriptive text textbook for class VII SMP/MTs is declared very valid and suitable for use by VII grade SMP/MTs students.
\end{abstract}

Keywords: Teaching Materials, Descriptive Text, Higher Order Thinking Skills, HOTS

\section{Introduction}

The description text is a text that is conveyed by describing the object in detail through sensory observation so that the reader seems to be able to see, hear, feel, and experience directly what object is described in accordance with the image of the author.

Higher order thinking skills are part of the achievement of skills to realize 21 st century learning where we are asked to learn to know, learn to do, learn to be, and learn to live together. These four principles should be needed and empowered in learning process activities such as communication skills, literacy, critical thinking skills, creative thinking skills, and other supporting skills so that you can get in touch to build cooperation so you can make wise decisions [22, 24].

Based on a need analysis study conducted by researchers by five Indonesian language teacher respondents regarding the types of teaching materials needed in schools, the content of teaching materials, HOTS learning resources, and the appearance of HOTS teaching materials books, it has not been found much. Because most of the teachers do not understand how to distinguish HOTS teaching materials or not, then educators do not know whether the teaching materials used in HOTS schools or not, even when the learning process is teacher-centered, then some students 
cannot describe what they are learn in school with the skills needed in real life. Therefore, based on this, HOTS-oriented teaching materials are needed by Indonesian language subject teachers. Because the learning process that takes place in schools so far still uses one source of textbooks from the government, so that supporting student and teacher learning activities are limited and their way of thinking is not developed. Narrowness of teaching materials can also affect the shallow process of students' knowledge. In addition, the characteristics of the implementation of the 2013 curriculum should be able to stimulate students' critical and creative thinking skills so that they can create or produce works. Learning researchers hope is to be at a higher level both on cognitive, affective, and psychomotor indicators. This can be strengthened by the results of five Indonesian teacher respondents who stated that from the element of using the type of teaching material, it got 3.4, the second the contents of the teaching material got 3.52, the three HOTS learning resources got 3.53 and the fourth was the appearance of the HOTS teaching material book got 3.8 . So that the average score obtained is 3.6 (really need). In this case, it means that printed teaching materials are needed in the form of HOTSoriented descriptive textbooks for seventh grade students of SMP/MTs as teaching materials to help educators or teachers through the appropriate learning process in class.

From some of these problems, it is necessary to develop teaching materials $[10,11]$. The teaching materials developed are teaching materials oriented to higher order thinking skills. "Teaching materials are all forms of material that are used to assist teachers or instructors in carrying out the learning process in the classroom, these materials can be in the form of written or unwritten language."[16].

The HOTS description textbook teaching materials have been prepared by researchers in accordance with the 2013 Revised curriculum (Permendikbud Number 37 of 2018 concerning amendments to Permendikbud Number 24 of 2016 on Primary and Secondary Education. So that Core Competencies and Basic Competencies of Curriculum 2013 for SMP/MTs can be achieved. There are two competencies that must be achieved and conveyed in the learning process, namely KI-3 which contains knowledge competencies, namely (factual, conceptual, and procedural) based on his curiosity about science and KI-4 contains skills competencies (trying, processing, and presenting in the realm of the concrete (using, parsing, arranging, modifying, and making) and the realm of the abstract (writing, reading, composing) according to what schools and other sources learn." $[8,14]$.

Presentation of material and questions on the KI-3 competency is presented in the student description textbook with the activity of identifying the descriptive text information that students hear and read. While the presentation of material and questions on the KI-4 competence is presented in the student book through the activity of presenting data, ideas, impressions in the form of written and oral descriptions by paying attention to structure, language, both oral and written.

However, in the meantime the researcher only examines
$\mathrm{KD} 3.2$, which examines the structure and rules of language from the descriptive text both from mass media in the form of books and digital media downloaded from the internet which can then be used as development material in analysis, evaluation, and creation activities in which includes four basic competencies that are taught, especially the descriptive text material for class VII SMP/MTs (seven graders of secondary schools). Based on this, research conducted by Jaja, Mudopar, Maya, Hesti [12] states that the linguistic aspects contained in the seven text genres in grade VII SMP studied are diverse, in the sense that they include many linguistic rules, starting from the level of phonology, morphology, syntax, and semantics. This term varies because to express the structure of a building one can use other linguistic elements, and the aspects of language used in each component of the structure of the text represent the characteristics of the text genre according to its social function. Although the building blocks are the same, the choice of aspects and forms of language can be different. The aspects of the language being taught are still incomplete and general (http://jurnal.ugj.ac.id/index.php/jurnaltuturan/article/view/2 868)

The development of HOTS-oriented descriptive textbooks has been equipped with instructions for the scientific approach contained in the 2013 curriculum which consists of observing, asking questions, gathering information, associating, communicating, and creating activities. In addition, the scientific approach in this book is equipped with a HOTS column which is intended to help teachers and students during its implementation. Explanation of the forms of activities contained in this book, indicators of observing are contained in activities, let's pay attention, indicators of asking are contained in activities, let's analyze, indicators of associating or reasoning are contained in activities, let's evaluate and let's analyze, and indicators to communicate contained in activities let's reflect.

The success of learning objectives with HOTS-oriented teaching materials can be seen when teachers and students are able to understand and apply the learning principles in Permendikbud No. 22 of 2016 which explains that students should be equipped to find out a lot rather than tell, teachers are no longer the only source of learning but when learning teachers must change their way of thinking to be based on various learning resources, learning that has been based on content should be creative into competency-based learning, the contextual approach is increasing towards a scientific approach, and the learning process carried out by the teacher which initially only requires a single answer, is improved to innovate towards learning that emphasizes multidimensional answers.

Thus, the hope of researchers is how to be able to create and develop HOTS-oriented descriptive text teaching materials with a research focus on the preparation of questions that contain the stages of analyzing, evaluating and creating, so that each description text topic contains elements of high order thinking skills [15, 20].

Furthermore, the formulation of the research problem is presented as follows: 1) What is the structure and language 
rules of descriptive text in print and digital media which are oriented towards higher order thinking skills?; 2) How is the design of descriptive text teaching materials oriented to highlevel thinking skills in SMP in Indonesian class VII subjects?; 3) How is the implementation of descriptive text teaching materials oriented to higher order thinking skills for class VII SMP/MTs?

\section{Literature Review}

\subsection{Research and Development}

This study aims to obtain new products through several stages of development [7]. Research and development are a process or method used to validate and develop products [23]. In order to improve the quality of education, the authors state that this method is very appropriate to be implemented in order to develop a model.

Based on several opinions about research and development above, Sugiyono theory is the basis used in concluding the theory. Furthermore, the authors can conclude that research and development is the manufacture of new products related to the development process in education such as textbooks, development methods, media, instruments and other devices to be accounted for.

\subsection{Description Text}

Description texts are taught and studied in Indonesian language lessons in class VII SMP Odd Semester 2013 curriculum. The researchers focused on developing descriptive text teaching materials that can be used for learning Indonesian both by teachers as educators and students through a proper learning process that aims to build critical and creative thinking skills through the presentation of questions oriented to analysis, evaluation, and creation.

A form of writing that is related to the efforts of the authors to provide details of the object under discussion is called a descriptive text [13]. Tomkins [25] states that writing is as if "depicting a picture using words." Thus, the description is used by the writer to use a state or situation, the character of the object comprehensively, by relying on vocabulary. In this case, according to Finoza, description is a form of writing that aims to expand the knowledge and experience of readers by depicting the true nature of the object [6].

Based on several opinions about the description above, Zainurrahman theory is the basis used in concluding the theory of descriptive texts. Furthermore, the author can conclude that the meaning of descriptive text is a text that describes objects in detail that are captured by the senses so that they can describe certain conditions, forms, or situations as if the reader is able to see, hear, smell, or even experience directly the object in accordance with the author's image.

\subsection{Development of Teaching Materials}

\subsubsection{Basic Learning Materials Development}

The development of teaching materials carried out by the author is based on a scientific foundation with indicators of the accuracy of a material, material presentation, and other supporting material. Then proceed with being based on education and teacher science by paying attention to indicators of the meaning of the nature of learning, the use of models, methods and learning media, student motivation and creativity, and the development of learning activities. Furthermore, the authors pay attention to the relationship between student needs related to motivation or interest in learning. Therefore, the motivation of students plays an important role in supporting the achievement of students' thinking competencies. Then finally, the writer pays attention to the readability indicators of the aspects of the presentation of the material and the language that is implemented, for example the material and language used is coherent, straightforward, interactive, and in accordance with student development related to the use of linguistic rules or general guidelines for correct Indonesian spelling [18]. Furthermore, the Indonesian language textbook that is assessed is based on four criteria, namely as follows: 1. appropriateness of the content or material used; 2. eligibility on presentation elements; 3. appropriateness of language elements; and feasibility of graphic elements [18].

\subsubsection{The Essence of Teaching Materials}

The teaching material books that the author developed are teaching materials in the form of teaching material books, which are textbooks that are prepared for the learning process which contain learning materials that will be described in teaching materials. As for Prastowo [2] says that teaching material books are books that are designed for the learning process and contain learning materials or materials to be taught.

Based on the explanation above, it can be concluded that the book is classified into printed teaching materials containing the presentation of material and other devices to be used as a learning process for teachers and students while participating in learning activities so as to achieve the desired goals to make it easier for students to learn so that the teaching materials can meet the requirements curriculum needs.

\subsubsection{Basic Development of HOTS Oriented Descriptive Text Teaching Materials}

The government wants students to achieve competency through the application of higher order thinking skills. This competence can be obtained by practicing the ability to communicate, work together, think critically, think creatively and innovatively, and have confidence. This is done in order to meet 21 st century learning skills which have the main principles of learning that are applied centered on students, are collaborative, contain contextual, and are integrated in society [24].

\subsection{Higher Order Thinking Skills}

To achieve the goal of orientation in higher order thinking skills, students must first learn, understand, and master the 
initial levels of the thinking process, namely remembering, understanding, and applying. It is not enough for students to just understand at a low or initial level of thinking. However, other higher-order skills are also needed, namely higherorder thinking skills consisting of analysis, evaluation, and creation [3]. It should be noted that Higher Level Thinking Skills (HOTS) are different from HOT (Higher Level Thinking). Referring to the revised Bloom's Taxonomy, HOT is related to cognitive abilities in analyzing, evaluating, and creating. Meanwhile HOTS relates to the ability to solve problems, think critically, and think creatively [21].

Krulick and Rudnick start from the lowest level to higher order thinking, namely: recall thinking, basic thinking, critical thinking (critical), and creative thinking. [4, 9]. Brookhart 2010 explained that HOTS types are based on class objectives, namely: 1) HOTS as knowledge transfer is defined as applying knowledge and skills that have been developed in learning in a new context; 2) HOTS as problem solving (analyzing, evaluating and creating); and 3) HOTS as critical thinking criticizes something using scientific and logical reasons $[5,19]$.

Based on this, the Sani theory becomes the basis used in concluding the theory of higher order thinking skills. Furthermore, the authors concluded that the category of analysis and evaluation is part of critical thinking. Meanwhile, the category of creating is part of creative thinking.

\section{Method}

The method used in this research is the ADDIE model research and development method. The explanation for the development of ADDIE model teaching materials is as follows.

\section{1) Analysis Phase}

The needs analysis regarding HOTS-oriented descriptive textbooks for grade VII SMP/MTs (seven graders of secondary schools) students conducted at MTs Negeri 3 Indramayu, State junior high school 1 Karangampel, and SMP NU Kaplongan produced questionnaire data for Indonesian language teachers interviews related to the teaching materials needed based on the type of teaching material, contents of teaching materials, HOTS learning resources, and display of teaching materials.

\section{a. Needs analysis}

Needs analysis was carried out to see the teaching material needs for learning Indonesian text descriptions through filling out an interview questionnaire. This is done so that the development carried out is in accordance with the objectives of the researcher, namely to obtain the teaching material needs of teachers regarding HOTS-oriented description textbooks for grade VII SMP/MTs (seven graders of secondary schools).

\section{b. Curriculum analysis}

Researchers analyzed the curriculum used against core competencies and basic competencies in Indonesian language learning problems, descriptive text material and analysis of the use of recommended teaching materials in the curriculum used.

\section{c. Material Analysis}

Collecting and analyzing the necessary materials, namely in the form of descriptive text from both mass and electronic media.

\section{2) Design Stage}

The description of this design stage is explained as follows.

a. Format Selection. The format selection used is the content of the book and the form of the design of the teaching material book design.

b. The book design is designed in accordance with the basic competencies, syllabus and HOTS orientation of the material and the presentation of descriptive text questions for class VII SMP/MTs (seven graders of secondary schools). The steps for making a product design are as follows.

I. The opening of the book. Namely consisting of covers, preface, table of contents, and instructions for book elements so that they are easy to learn, namely general instructions, HOTS columns, scientific columns and concept maps, text descriptions in the form of basic competencies that must be mastered and determine indicators of competency achievement.

II. The contents of the book consist of the following elements;

III. 1) determine the description text learning objectives chart; 2) determine the presentation of the material composition; 3) determine and arrange the presentation of questions; 4) Determine student activity assignments; 5) determine the student activity answer sheet; 6) determine the evaluation sheet; 7) determine the type of letter, space, and size in the preparation of the teaching material book. The type and size of the letter in the title of the chapter is 14 with the font Times New Roman, in the section it is 12 with the font of Times New Roman, on the other font size which is 12 and the font in Times New Roman with a space of 1.5; and 8) arranging and determining the varied color collaborations in the teaching material book.

IV.The closing. At the end of the book, the author compiles and determines the contents of the glossary, author's biography, bibliography, and the back cover of the book.

\section{3) Development Stage}

Until this third stage, the researcher started to develop the product, namely determining the HOTS content (analysis, evaluation, and creation) and the design content of the book content, namely as follows.

a) HOTS content, which is described as follows.

(1) Contains things that are really needed in the learning process of the descriptive text. These matters are about understanding and identifying the characteristics andpurpose of the description text, determining the 
contents of the description text object, examining the structure and linguistic rules of the description text, and presenting data, ideas, impressions in the form of descriptive text, and other exercises about answering questions about the description text, so that students' knowledge of the description text can be understood properly.

(2) Contains the presentation of questions that are highlevel oriented or have HOTS indicators which are described as follows. 1) analyzing the description text based on its structure and language, 2) analyzing the relationship between descriptive text and other texts, 3) analyzing the application of descriptive text in everyday life, 4) evaluating problem solving in the material, and 5) being able to write ideas in descriptive text in everyday life.

(3) Generating (questions with short answers, essays, and performance)

(4) Explain (give reasons for a choice or answer to a question

(5) Select the answer (multiple choice questions) for the evaluation sheet

b) Design the book content

(1) Consists of information in the form of several competency stages that teachers and students need to understand and study, namely as follows.

Table 1. Competency Stages.

\begin{tabular}{ll}
\hline Competency Stages & Explanation \\
\hline let's read & Contains material that students need to know and read \\
Let's analyze & Contains questions or statements to which you must find the answer \\
Let's evaluate & Contains exercise HOTS questions to review the material that has been studied by students \\
Let's create & Contains student worksheets that students must produce \\
pay attention & Contains material presentation sheets about examples of types of descriptive text that must be considered by students \\
Let's try & Contains questions or orders that must be carried out by students and answered based on analysis \\
Let's reflect & Contains self-correcting sheets about the lessons that students have learned \\
\hline
\end{tabular}

(2) Involves a scientific approach in the following process skills. The scientific approach to the HOTSoriented description textbook for grade VII SMP/MTs is contained in the following activities.

i) Observe: contained in the activity "Let's Pay Attention

ii) Asking: contained in the activity "Let's Analyze" iii) Gathering Information: contained in the activities "Let's Read" and"Let's Try"

iv) Associating (Reasoning): contained in the activities "Let's Analyze" and"Let's Evaluate"

v) Communicating: contained in the activity "Let's Reflect"

Table 2. Scientific Skills

\begin{tabular}{ll}
\hline Skills in Scientific & Information \\
\hline Observe & $\begin{array}{l}\text { Presenting the object of examples of descriptive text in real terms, so that students are happy and challenged and } \\
\text { have high meaning in the hope that students can find facts by analyzing. } \\
\text { The activity of asking questions is expected to arise from students to get additional information about what is } \\
\text { observed. This activity aims to develop the curiosity of students. }\end{array}$ \\
Asking & $\begin{array}{l}\text { Activities undertaken to explore and collect information from various sources through reading books, paying } \\
\text { attention to phenomena or objects that are more thorough and experimenting. }\end{array}$ \\
Gathering Information & $\begin{array}{l}\text { Activities to process information that has been collected from observing activities } \\
\text { Activities communicate the information they have learned through writing, telling, practicing information seeking } \\
\text { Associating (Reasoning) }\end{array}$ \\
\hline
\end{tabular}

At this stage, data processing or materials related to Indonesian language learning will be carried out with descriptive text material and then compiled into teaching materials in the form of textbooks. Furthermore, in the final stage of the development of this teaching material is the process of changing the appearance of the teaching material into a printed teaching material book in the form of a book and stored in a file or document.

\section{4) Implementation Stage}

At this stage, the researchers tested the teaching material products by expert lecturers, namely material and media experts, which then revised the product according to suggestions and input from the teaching material expert team. In addition, the implementation of teaching materials was also carried out for practitioners, namely three Indonesian language teachers from three schools by filling out the analysis questionnaire that the researcher had provided.

\footnotetext{
5) Evaluation Phase
}

At this stage, the researcher evaluates the teaching materials that have been tested based on the results of the implementation. Furthermore, after being evaluated by a team of teaching material experts, namely material experts and media experts as well as three Indonesian language teachers to get suggestions and improvements to the product. Through three Indonesian language teachers, the results of the teacher's assessment and impressions of the HOTSoriented description textbook were obtained to be used as a conclusion until the product was declared good and suitable for use. At this stage, the researcher made the final revision of the Indonesian language teaching material that was developed based on the input obtained from the teacher's response questionnaire or field notes on the observation sheet. It is intended that the Indonesian language teaching materials developed are truly feasible and can be applied to learning in schools. 


\section{Results and Discussion}

\subsection{The Results}

\subsubsection{Analysis of Teaching Material Needs}

Researchers conducted an analysis of the needs of teaching materials used in schools to five Indonesian language teacher respondents. The aim is that this is done as the initial basis for researchers to create and compile the teaching materials needed in the process of developing HOTS-oriented teaching materials. The indicators or aspects used in filling out theneedsquestionnaire are the use of the type of teaching material, the second the content of the teaching material, the three HOTS learning resources, and the fourth is the display of the HOTS teaching material book. The results of the average needs questionnaire are presented as follows.

Table 3. Results of the Needs Analysis by Five Indonesian Language Teacher Respondents.

\begin{tabular}{llll}
\hline Number & Aspect & Average $(\mathbf{n}=\mathbf{5})$ & information \\
\hline 1. & Types of teaching materials & 3,4 & Need \\
2. & Fill in teaching materials & 3,52 & Really need \\
3. & HOTS learning resources & 3,53 & Really need \\
4. & Display of HOTS teaching & 3,8 & Really need \\
& materials & 3,6 & Really need \\
\hline
\end{tabular}

The results of the analysis of the need for HOTS-oriented descriptive text teaching materials by five Indonesian language teacher practitioners from the aspect of the type of teaching materials stated that the HOTS book teaching materials needed to help convey descriptive text material in class VII SMP/MTs (seven graders of secondary schools). This is evidenced by the results of practitioner one getting 4 points, practitioner two getting 4 points, practitioner three getting 3 points, practitioner four getting 3 points, and practitioner five getting 3 points. get 3,4 results (Need)

The results of the analysis of the need for teaching materials for HOTS-oriented descriptive texts by five Indonesian language teacher practitioners from the aspect of the content of teaching materials stated that they really need the content of teaching materials with indicators: a) concept maps, b) able to improve student understanding, c) can improve students' creative thinking skills, d) the presentation of various and interesting activities, and e) contains exercises on HOTS to foster critical and creative thinking in students. This is evidenced by the results of practitioner one getting 4 3443 points, practitioner two getting 43343 points, practitioner three getting 33434 points, practitioner four getting 44343 points, and practitioner five get 43344 . So, the number obtained by practitioner one is 19 , practitioner two is 16 , practitioner three is 17 , practitioner four is 19 , and practitioner five is 17 . Furthermore, from each number of practitioners divided by 5 respondents get the practitioner's results one $(3,8)$, practitioner two $(3,2)$, practitioner three $(3,4)$, practitioner four $(3,8)$ and practitioner five $(4,4)$. So, it can be concluded that the total number of elements of the content of teaching materials gets a score of 17.6 divided by 5 from the elements of the content of teaching materials, namely getting a score of 3.52 (really need).

The results of the analysis of the need for HOTS-oriented descriptive text teaching materials by five Indonesian language teacher practitioners from the HOTS learning resource aspect state that they really need an indicator: a) requires analyzing activities in textbooks to train students to solve a problem, b) requires evaluating activities on books to stimulate thinking critical students, and c) need creative activities in books to stimulate students' creative thinking. This is evidenced by the results of practitioner one getting 4 3334 points, practitioner two getting 44433 points, practitioner three getting 343 points, practitioner four getting 334 points, and practitioner five getting 34 points. 3 44 . So that the total amount obtained by practitioners from the HOTS learning resource aspect is 10.6. So, it can be concluded that the overall number of HOTS learning resource elements gets a score of 10.6 divided by 5 respondents getting a score of 3.53 (really need).

The results of the analysis of the need for HOTS-oriented descriptive text teaching materials by five Indonesian language teacher practitioners from the aspect of the display of teaching materials stated that they really need a HOTS display book equipped with a concept map, material presentation, systematic and interesting student activities for students to learn. This is evidenced by the results of practitioner one getting 4 points, practitioner two getting 4 points, practitioner three getting 3 points, practitioner four getting 4 points, and practitioner five getting 4 points. So that the number obtained is 19 . Furthermore, the number of 19 is divided by 5 respondents. get 3.8 results (really need).

Based on the final score obtained from all 5 respondents regarding HOTS-oriented teaching materials needed by researchers. So, it can be concluded from the element of using the type of teaching materials got 3.4, the two contents of the teaching materials got 3.52, the three HOTS learning resources got 3.53 and the fourth was the appearance of the HOTS teaching materials book got 3.8. So that the average score obtained is 3.6 (really need). In this case, it means that printed teaching materials are needed in the form of HOTSoriented descriptive textbooks for seventh grade students of SMP/MTs as teaching materials to help educators or teachers through the appropriate learning process in class.

Table 4. Analysis of HOTS Teaching Materials Needs Description Text

\begin{tabular}{lll}
\hline Assessment & Category & Information \\
\hline Score 4 & Really need & $3,50<\mathrm{RV}<4,00$ \\
Score 3 & Need & $2,50<\mathrm{RV}<3,50$ \\
Score 2 & Less Need & $1,50<\mathrm{RV}<2,50$ \\
Score 1 & No need & $1,00<\mathrm{RV}<1,50$ \\
\hline
\end{tabular}

Based on the table statement, HOTS-oriented descriptive textbooks can be declared to meet the criteria with a minimum need category if they get an average score of 2.50 $<\mathrm{RV}<3.50$ with the Need (B) category which is used as a basis for developing teaching materials HOTS corresponds to the creativity and innovation that researchers have determined to be able to think critically and think creatively. 


\subsubsection{Research Results}

The structure and language of the descriptive text from print and digital media in the form of objects (schools, tourist attractions, historical places, and / or local art performances) can be used as examples and descriptive text material in the teaching materials that have been developed. The explanation is as follows.

a) Based on the study of the structure of the descriptive text, it is concluded that not all descriptive texts can be used as teaching materials. Texts that can be used as teaching materials are those that have a complete structure, namely a general description or identification, a description of the section, and a conclusion (a conclusion or affirmation of important matters) [17]. The description text which has a complete description structure is found in the descriptive text: 1) Green House (Green House) in my school garden, 2) My School Canteen, 3) School library, 4) Dolphin bay, 5) National Monument, 6) The magic of Kecak dance at Pura Luhur Uluwatu, and 7) The joy of performing arts at my school. Meanwhile, the text description 8 entitled "Saman Dance" does not have a complete text structure, only in the form of a general description and part description. Therefore, the materials used for the development of descriptive text teaching materials are text 1 , text 2 , text 3 , text 4 , text 5 , text 6 , and text 7 .

b) Based on the study of linguistics in the description text, it is concluded that the dominant language aspects are used, namely: text 1 (Green House (Green House) in my school garden), text 2 (my school canteen), text 4 (Teluk Dolphins), text 5 (National Monument), and text 6 (The magic of Kecak Dance at PuraLuhurUluwatu) which is described in the following aspects: a) Uses detailed sentences, b) Contains descriptive adjectives, c) Uses copula, d) Uses conjunctions, e) contain prepositions, f) Use material verbs, and g) Use language words.

The design of the development products developed by the author based on the research results is in the form of a book entitled HOTS-Oriented Description Text for Class VII SMP/MTs (seven graders of secondary schools).

The resulting development product is equipped with text content, images, concept maps, descriptive text learning objective charts, and types of text descriptions and presentation of material and questions consisting of several activities that are packaged with several images adapted to the type of text. as well as varied colors and accompanied by student answer sheets to encourage student thinking stimuli. Meanwhile, the components of the description textbook development product are HOTS oriented, namely the first book cover, which contains front and back covers. The first two parts of the book contain a copyright page, a foreword page, a table of contents, a general guide for the book, a HOTS column, a scientific column, a concept map, and a description text learning objective. Furthermore, the three content sections, which contain the contents of the book, are divided into 4 (four) Basic Competencies of Descriptive Text Class VII SMP/MTs (seven graders of secondary schools). Basic competencies in the contents of the book generally consist of A) Identifying Information in the Description Text, B) Determining / Explaining the Content of the Descriptive Text, C) Examining the Structure and Rules of Language of the Description Text, and D) Presenting Data, Ideas, and Impressions in Text Description. Furthermore, the fourth is the final part of the book, which contains a bibliography, glossary, and biography of the author.

\subsubsection{Feasibility Analysis of Teaching Material Development}

The eligibility criteria for teaching materials according to Akbar [1] are as follows.

Table 5. Development feasibility of teaching materials

\begin{tabular}{lll}
\hline Number & $\begin{array}{l}\text { Percentage of } \\
\text { Questionnaire Calculation }\end{array}$ & Assessment criteria \\
\hline 1 & $85,01 \%-100,00 \%$ & $\begin{array}{l}\text { very valid, or can be used } \\
\text { without revision. } \\
\text { quite valid, or can be usedbut } \\
\text { needs a little revision, }\end{array}$ \\
2 & $70,01 \%-85,00 \%$ & $\begin{array}{l}\text { Not valid, not recommendedused } \\
\text { because it needs a lot of revision. } \\
3\end{array}$ \\
$40,01 \%-70,00 \%$ & Invalid, or may not be used \\
\hline
\end{tabular}

\subsubsection{Data Analysis of Expert Lecturer Validation Results}

The results of the validation of material experts and media experts are as follows. The feasibility assessment of the product development of HOTS-Oriented Descriptions Textbooks was declared fit for use as a source of teaching materials consisting of the results of validation by material experts namely: DadunKohar (Lecturer in Indonesian Language, University of WiralodraIndramayu) and Indri Mulyaningsih (Lecturer Indonesian IAIN SyekhNurjati Cirebon) as a validator of material experts I and II obtained an average rating of all aspects of the assessment of 4.2 in the Good category. With details of the average score of each aspect of the assessment, namely; the feasibility of the material is 4 (Good), the feasibility of the language is 4.2 (Good), the feasibility of the presentation of the material is 4.3 (Very Good), and the feasibility of the graph is 4.2 (Good).

Meanwhile, the results of the media expert validation, namely DadunKohar (Lecturer in Indonesian Language, University of WiralodraIndramayu) andIndri Mulyaningsih (Lecturer Indonesian IAIN SyekhNurjati Cirebon) as a validator of media experts I and II obtained an average assessment of all aspects of the assessment of 4.1 in the Good category. With details of the average score of each aspect of the assessment, namely; Content eligibility is 4 (Good), linguistic feasibility is 4.2 (Good), display eligibility is 4.3 (Very Good), and graphical feasibility is 4 (Good).

The results of the evaluation of the validation recapitulation of the two validators and the feasibility aspect of the developed descriptive text teaching materials meet the eligibility criteria "Good (B)" from the combined acquisition of validator I and validator II as material experts with an average score of 4.2 and a percentage of $84 \%$ ). Meanwhile, the results of the validation recapitulation assessment obtained from a combination of validator I and validator II as 
media experts meet the eligibility criteria with the criteria of "Good (B)" with an average score of 4.1 and a percentage of $82 \%)$. Thus, it can be concluded that the product of HOTSOriented Description Textbook development for Class VII SMP/MTs (seven graders of secondary schools) students is said to be Good (B) based on the results of the evaluation of validators I and II as material experts and based on the assessment of validators I and II as media experts. However, in order to improve the book, the author of the revision received suggestions from expert lecturers so that the book could be declared fit for use.

\subsection{Discussion}

The product of making descriptive text books that the author has developed is entitled HOTS-Oriented Description Textbooks for Class VII SMP/MTs (seven graders of secondary schools). This lesson enrichment book was written to meet the elements of KD grade VII. The results of the validation of Indonesian language teachers (practitioners) can be explained as follows.

Data Analysis of the Implementation Results of Indonesian Language Teachers

The results of the assessment given by the Indonesian Language Teacher showed that the enrichment book made by the researcher was declared very valid as evidenced by the results of the explanation as follows.

The filling out of the teacher assessment questionnaire on the HOTS-oriented description textbook for class VII SMP/MTs was carried out by 3 class VII teachers consisting of one teacher at SMPN 1 Karangampel, one SMP NU Kaplongan teacher, and one MTS NU 3 Indramayu teacher. The aspects that become the teacher's assessment of the textbook include: 1) The content of the material, 2) Language, 3) Presentation of the material, 4) Graphics, and 5) HOTS components. Obtained an overall average score of 268 based on 3 teachers is $89.3 \%$.

Based on the summation results, it can be obtained an average value of $89.3 \%$ from the teacher's assessment questionnaire on HOTS-Oriented Description Textbooks for Class VII SMP/MTs (seven graders of secondary schools). Thus, the teacher's response to the feasibility of the book which was obtained based on the average score of the questionnaire showed that HOTS-oriented description books for grade seven graders of secondary schoolswere very valid.

\section{Conclusion}

Based on the results of the Material Expert validation with the results of the assessment of $84 \%$ (valid) and the results of the validation of the Media expert of $82 \%$ (valid) and the results of the evaluation of the implementation of $89.3 \%$ are very valid, it can be concluded that the HOTS Oriented Description Textbook for Class VII SMP/MTs (seven graders of secondary schools) is declared very feasible or can be used in schools as a process of learning Indonesian with highorder thinking skills oriented.

\section{References}

[1] Akbar, Sa'dun. (2013). Instrumen Pengembangan Pembelajaran. Bandung: Rosdakarya.

[2] Andi Prastowo. (2014). Panduan KreatifMembuatBahan Ajar Inovatif. Yogyakarta: Diva.

[3] Anderson, L. W., dan Krathwohl, D. R. (2001). A Taxonomy for Learning, Teaching and Assesing. New York: Addison Wesley Longman Inc.

[4] Aprianti. (2013) Definisi Sikap Percaya Diri. Skripsi Prodi PGSD. Universitas Pasundan Bandung: tidak diterbitkan.

[5] Brookhart, S. M. (2010). How to Assess Higher-Order Thinking Skills in Your Classroom. United States of Amerika: ASCD Member Book.

[6] Dalman. (2015). Menulis Karya Ilmiah. Depok: Raja grafindo Persada.

[7] Mulyatiningsih. (2014). Metode Penelitian Terapan Bidang Pendidikan. Bandung: ALFABETA.

[8] Harsiati, Titik dkk. (2017). Bahasa Indonesia. Kemendikbud: Pusat Kurikulum dan Perbukuan, Balitang.

[9] Helmawati (2019). Pembelajaran dan Penilaian Berbasis HOTS Higher Order Thingking Skills. Bandung: PT Remaja Rosdakarya.

[10] Jaja, \& Karlinah. (2019). Analisis Teks Ulasan Film Dari Media Elektronik Google Dan Pemanfaatannya Sebagai Bahan Ajar Untuk Siswa Smp/Mts Kelas Viii. Deiksisa-Jurnal Pendidikan Bahasa Dan Sastra Indonesia, 36-42.

[11] Jaja, \&Rimayanti, A. I. (2018). Pengembangan Bahan Ajar Teks Eksplanasi Berdasarkan Berita Media Massa Cetak. Jurnal Tuturan, Vol. 7, No. 2, 857-862.

[12] Jaja, Mudopar, Maya, Hesti "Representasi Aspek Linguistik dalam Genre Teks dalam Bahasa Indonesia SMP Buku Pelajaran dalam Kurikulum 2013" (Jurnal Tuturan, nomor 2, volume $\quad 8 \quad$ tahun 2019) https://www.atlantispress.com/proceedings/isseh$18 / 55915164$.

[13] Keraf, Goris.(2007). Eksposisi dan Deskripsi. Jakarta: PT Gramedia.

[14] Kemendikbud. (2013). Buku Guru Bahasa Indonesia Ekspresi diri dan Akademik. Jakarta: Kementrian Pendidikan dan Kebudayaan.

[15] Kemdikbud. (2016). PanduanPenyusunanSoal Higher Order Thinking Skills (HOTS). Jakarta: Direktorat Pembinaan SMA Dirjen Pendidikan Menengah Kemdikbud.

[16] Lestari, Ika. (2013). Pengembangan Bahan Ajar Berbasis: sesuai dengan Kurikulum Satuan Pendidikan. Padang: Akademia Pendidikan.

[17] Mahsun (2014). Teks dalam Pembelajaran Bahasa Indonesia Kurikulum 2013. Jakarta: PT Raja Grafindo Persada.

[18] Muslich, Masnur. (2010). Text book writing: dasar-dasar pemahaman, penulisan dan pemakaian Buku Teks. Yogyakarta: Ar-Ruzz Media. 
[19] Nugroho, R. Arifin. (2018). HOTS (Kemampuan Berpikir Tingkat Tinggi) Konsep, Pembelajaran, Penilaian, dan soalsoal. Jakarta: PT Gramedia Widiasarana Indonesia.

[20] Nurhayati, dkk. (2018) "Analisis Kemampuan Menulis Karangan Deskripsi dalam Bahasa Indonesia Melalui Media Gambar Seri". Jurnal Ilmu Budaya, Volume 6, Nomor 2, Desember 2018.

[21] Sani, Ridwan Abdullah. (2019). Pembelajaran Berbasis HOTS (Higher Order Thinking Skills) Edisi Revisi. Tangerang: Tira Smart.

[22] Subadar. (2017). Penguatan Pendidikan Karakter (PPK) Berbasis Higher Order Thinking Skills (HOTS). Jurnal Pedagogik. Vol. 04 No. 01.
[23] Sugiyono. (2015). Metode Penelitian Pendidikan (Pendekatan Kuantitatif, Kualitatif dan $R \& D)$. Penerbit CV. Alfabeta: Bandung.

[24] Widihastuti. (2015). Model Penilaian untuk Pembelajaran Abad 21 (Sebuah Kajian untuk Mempersiapkan SDM Kritis dan Kreatif). Prosiding Seminar Nasional Pengembangan SDM Kreatif dan Inovatif untuk Mewujudkan Generasi Emas Indonesia Berdaya Saing Global pp. 77-86, Universitas Negeri Yogyakarta.

[25] Zainurrahman. (2013). Menulis: Dari Teori Hingga Praktik (Penawar Racun Plagiarisme). Bandung: Alfabeta. 